\section{Effect of Composite Containing an Iodonium Salt on the Bond Strength of Brackets to Bovine Enamel}

Eveline Freitas Soares ${ }^{1}$, Ana Rosa Costa ${ }^{1}$, Américo Bortolazzo Correr ${ }^{1}$, Silvia Amélia Vedovello², Mário Vedovello Filho², Fabrício Aulo Ogliari³, Rafael Ratto de Moraes ${ }^{4}$, Lourenço Correr-Sobrinho ${ }^{1}$

\author{
'Department of Restorative \\ Dentistry, Dental Materials \\ Division, Piracicaba School of \\ Dentistry, UNICAMP - University of \\ Campinas, Piracicaba, SP, Brazil \\ ${ }^{2}$ Department of Orthodontics, \\ Graduate Program in Orthodontics, \\ UNIARARAS - University of \\ Araras, Araras, SP, Brazil \\ ${ }^{3}$ Materials Engineering School, \\ UFPel - Federal University of \\ Pelotas, Pelotas, RS, Brazil \\ ${ }^{4}$ Department of Restorative \\ Dentistry, School of Dentistry, \\ UFPel - Federal University of \\ Pelotas, Pelotas, RS, Brazil
}

Correspondence: Prof. Dr. Lourenço Correr-Sobrinho, Avenida Limeira, 901, 13414-903 Piracicaba, SP, Brasil. Tel: +55-19-2106-5345. e-mail: sobrinho@fop.unicamp.br

Key Words: shear bond strength, aging, bonding, Orthodontics, polymerization, composite.

\section{Introduction}

Metallic brackets are routinely bonded to the teeth using light-cured composite resins (1-3). The advantage of photoactivated composites is that the clinician has the control of working time to place the brackets in the correct position, easy removal of the excess composite and possibility of immediate insertion of the orthodontic archwire (4). Adequate early polymerization is necessary for brackets bond to the teeth resist the placement of the orthodontic archwire. However, complete polymerization of the composite may not be always possible when considering the clinically used light exposure times (5).

Composite material requires adequate light irradiance and wavelength (400-500 $\mathrm{nm}$ ) to activate the photosensitizer camphorquinone (CO), which reacts with an amine coinitiator to generate free radicals for polymerization $(6,7)$. According to the manufacturers' instructions, light exposure times between 20 and $40 \mathrm{~s}$ are required to bond brackets to the teeth to obtain high bond strength (8). However, long exposure times are uncomfortable for the patient and present drawbacks for the clinician (9).

Some methods to reduce the light-curing time for bonding orthodontic brackets are proposed in the literature $(2,9-12)$. The main method proposed is using light-curing units with high irradiance (e.g. xenon plasma arc and lasers) for fast polymerization $(13,14)$, but these units are expensive. Another alternative is the use of an iodonium salt. It has been reported that the use of iodonium salt has shown satisfactory results for dental adhesives when used associated with CO (15). The theory that explains the performance of iodonium salts is that the $\mathrm{CO}$, after excited by the curing light, can promote decomposition of the iodonium salt and enhance the polymerization kinetics $(15,16)$.

Bond strength tests are usually carried out $24 \mathrm{~h}$ after the orthodontic brackets are bonded to the teeth. However, this is not what occurs in the clinical practice, where the insertion of the orthodontic archwire occurs minutes after the brackets are bonded. Several studies have shown that $24 \mathrm{~h}$ after the bonding procedure, the brackets bond strength increased in relation to the times of 5,10 , and 30 $\min (9,17,18)$. There is no consensus as regards the waiting time required before placing the brackets.

The aim of this study was to investigate the effect of the incorporation of a iodonium salt in experimental composites on the shear bond strength of metallic orthodontic brackets bonded to bovine teeth, using different storage times (10 min or $24 \mathrm{~h}$ ). The hypotheses tested were that 1) the incorporation of an iodonium salt in experimental composites would lead to higher shear bond strengths, 2) 
the storage time (10 min or $24 \mathrm{~h}$ ) would not affect the shear bond strengths, and 3) specimens light-activated for longer periods would have higher shear bond strengths.

\section{Material and Methods}

\section{Experimental Composites}

This study is a follow up of the investigations on the use of iodonium salts to improve the polymerization of resin-based dental cements $(9,19)$. The three experimental materials tested were obtained using diphenyliodonium hexafluorphosphate (DPIHFP; Sigma-Aldrich, Milwaukee, WI, USA) at molar concentrations of 0 (control), 0.5 , or $1 \%$. A model dimethacrylate co-monomer was obtained by mixing the monomers bisphenol-A glycidyl dimethacrylate (Esstech, Essington, PA, USA) and triethylene glycol dimethacrylate (Esstech) at a 70:30 mass ratio. The photoinitiating system consisted of ethyl-4 dimethylamino benzoate (EDAB; Sigma-Aldrich) and CO (Esstech), each added at a molar concentration of $1 \%$. Butylated hydroxytoluene $(0.1 \mathrm{~mol} \%)$ was added as radical scavenger. The blends were loaded with a 60 mass $\%$ of silanized strontium-based glass particles with $1 \mu \mathrm{m}$ average particle size to control composite viscosity and render it thixotropicity.

\section{Bonding Procedures}

Two hundred and seventy bovine mandibular incisors without cracks were collected. The teeth were embedded in self-curing acrylic resin (Clássico Produtos Odontológicos Ltda., São Paulo, SP, Brazil) using polyvinyl chloride tubes as molds, leaving the buccal face perpendicular to the horizontal axis. The buccal faces of all teeth were cleaned using a rubber cups with non-fluoridated pumice-water slurry for $10 \mathrm{~s}$, rinsed with air-water spray for $10 \mathrm{~s}$ and air-dried for $10 \mathrm{~s}$. The teeth were divided into 18 groups $(n=15)$, according to three experimental bonding materials (control, $\mathrm{C} 05$ and $\mathrm{C1}$ ); light-activation time (8, 20 and $40 \mathrm{~s}$ ) and storage time ( $10 \mathrm{~min}$ or $24 \mathrm{~h}$ ). The middle third of the buccal vestibular face of all teeth was etched with 37\% phosphoric acid gel (3M ESPE, St. Paul, MN, USA) for $30 \mathrm{~s}$, rinsed with air-water spray for $30 \mathrm{~s}$ and air dried for $30 \mathrm{~s}$. One layer of Single Bond 2 Adhesive (3M ESPE) was applied on the teeth, gently dried for $5 \mathrm{~s}$, and photoactivated for $10 \mathrm{~s}$ with a quartz-tungsten-halogen light-curing unit (XL2500; 3M ESPE) with $800 \mathrm{~mW} / \mathrm{cm}^{2}$ irradiance.

Stainless steel standard maxillary central incisor brackets (slot 0.022"; Ortodontia Morelli, Sorocaba, SP, Brazil) were positioned and seated firmly on the tooth surface. Excess bonding material was removed using a microbrush (KG Sorensen, Cotia, SP, Brazil) and lightactivation was carried out with one exposure on each of the four sides of the bracket, with total exposure times of 8,20 , or $40 \mathrm{~s}$. The specimens were stored in distilled water at $37^{\circ} \mathrm{C}$ for $10 \min$ or $24 \mathrm{~h}$.

\section{Bond Strength Testing and Failure Analysis}

The shear bond strength (SBS) test was conducted in a mechanical testing machine (Model 4411; Instron, Canton, MA, USA) using a knife-edged rod at a crosshead speed of $1.0 \mathrm{~mm} / \mathrm{min}$ until failure. A mounting jig was used to align the tooth-bracket interface parallel to the testing device. The SBS values were calculated in MPa and analyzed using three-way ANOVA and Tukey's test $(\alpha=0.05)$. After debonding, tooth and bracket surfaces were examined with a stereomicroscope (Olympus Corp, Tokyo, Japan) under $8 \times$ magnification. The Adhesive Remnant Index (ARI) (20) was used to classify the failure modes, according to: score 0 indicates that no bonding resin remained on the tooth; score 1 indicates that less than half of the bonding resin remained on the tooth; score 2 indicates that more than half of the bonding resin remained on the tooth; and score 3 indicates that all bonding resin remained on the tooth, along with a clear impression of the bracket mesh.

\section{Results}

The results for shear bond strength of brackets to teeth are shown in Table 1. For 10 min storage time, the control group showed significantly lower $(p<0.05)$ shear bond strengths than the other bonding materials for all light-activation times. After $24 \mathrm{~h}$ storage, the experimental composite $\mathrm{C} 1$ had significantly higher $(\mathrm{p}<0.05)$ SBS than the control composite when light-activated for 20 and $40 \mathrm{~s}$. No statistically significant differences ( $p>0.05$ ) were detected when light-activated for $8 \mathrm{~s}$. In the comparison of $\mathrm{C} 05$ and $\mathrm{C} 1$, no significant differences $(\mathrm{p}<0.05)$ were observed for storage time or light-activation time.

When the light-activation times were compared at 10 min storage time, the control group light-activated for 8 $s$ showed significantly lower shear bond strength $(p<0.05)$ than groups light-activated for 20 and $40 \mathrm{~s}$, except for the groups $\mathrm{C} 05$ and $\mathrm{C} 1(\mathrm{p}<0.05)$. At $24 \mathrm{~h}$, the $\mathrm{C} 1$ experimental composite light-activated for $40 \mathrm{~s}$ had significantly higher SBS $(p<0.05)$ than the group light-activated for $8 \mathrm{~s}$. No significant difference was detected for control group and C05 ( $p>0.05$ ). The SBS for $24 \mathrm{~h}$ storage time was significantly higher $(p<0.05)$ when compared to $10 \mathrm{~min}$ for all groups (bonding material or light-activation time). The results for ARI are shown in Figure 1. There was a predominance of score 3 was observed for groups stored for $10 \mathrm{~min}$, and score 2 was the most frequent for groups stored for $24 \mathrm{~h}$.

\section{Discussion}

The first hypothesis tested was accepted. Generally, an increased SBS was observed when DPIHFP-modified agents were incorporated in experimental composites for all light- 
activation times. This finding is in agreement with a previous study with experimental composites, which also found significantly higher SBS in relation to the control group, but using diphenyliodonium chloride (DPC) as iodonium salt (9). The higher bond strength of experimental composites using DPIHFP-modified agents may be explained by the fact that the salt, even in low concentration, can promote higher polymerization reactivity. According to Ogliari et al. (15) the introduction of DPIHFP as co-initiator showed significant effect on the monomer conversion. In the ternary photoinitiator system, formed by CQ, EDAB and DPIHFP, the DPIHFP may react with inactive $\mathrm{CQ}$ radicals formed during polymerization to decrease the termination rate and improve the initiation rate by producing new radicals from the salt fragmentation, improving the monomer reactivity in relation to two-component initiator systems $(16,21,22)$.

Table 1. Mean shear bond strength values (S.D.) in MPa

\begin{tabular}{|c|c|c|c|c|}
\hline \multirow{2}{*}{$\begin{array}{l}\text { Storage } \\
\text { time* }\end{array}$} & \multirow{2}{*}{$\begin{array}{l}\text { Bonding } \\
\text { material }^{* * *}\end{array}$} & \multicolumn{3}{|c|}{ Light-activation time } \\
\hline & & $8 \mathrm{~s}$ & $20 \mathrm{~s}$ & $40 \mathrm{~s}$ \\
\hline \multirow{3}{*}{$10 \mathrm{~min}$} & Control & $4.6(1.5)^{\mathrm{b}, \mathrm{B}}$ & $6.9(2.2)^{\mathrm{b}, \mathrm{A}}$ & $7.1(2.5)^{\mathrm{b}, \mathrm{A}}$ \\
\hline & C05 & $8.1(2.4)^{\mathrm{a}, \mathrm{A}}$ & $9.2(2.1)^{\mathrm{a}, \mathrm{A}}$ & $9.9(2.8)^{\mathrm{a}, \mathrm{A}}$ \\
\hline & $\mathrm{C} 1$ & $9.1(2.91)^{\mathrm{a}, \mathrm{A}}$ & $10.4(3.9)^{\mathrm{a}, \mathrm{A}}$ & $10.7(3.3)^{\mathrm{a}, \mathrm{A}}$ \\
\hline \multirow{3}{*}{$24 \mathrm{~h}$} & Control & $10.9(2.8)^{\mathrm{a}, \mathrm{A}}$ & $11.1(3.2)^{\mathrm{b}, \mathrm{A}}$ & $11.7(3.1)^{\mathrm{b}, \mathrm{A}}$ \\
\hline & C05 & $11.8(2.7)^{\mathrm{a}, \mathrm{A}}$ & $12.7(4.0)^{\mathrm{ab}, \mathrm{A}}$ & $14.2(4.5)^{\mathrm{ab}, \mathrm{A}}$ \\
\hline & $\mathrm{C} 1$ & $12.1(4.2)^{\mathrm{a}, \mathrm{B}}$ & $14.4(4.4)^{\mathrm{a}, \mathrm{AB}}$ & $15.8(4.7)^{\mathrm{a}, \mathrm{A}}$ \\
\hline
\end{tabular}

*Significant differences were observed between $10 \mathrm{~min}$ and $24 \mathrm{~h}$ for all light-activation time and bonding material combinations $(p<0.05)$. ***C5 and C1 were formulated containing 0.5 and $1 \mathrm{~mol} \%$ of DPIHFP. For each storage time, means followed by different lowercase letters in the same column indicate significant differences for bonding material, and by different uppercase letters in the same row indicate significant differences for light-activation time (Tukey's test, $\mathrm{p}<0.05$ ).
An increase of the polymerization rate is advantageous to the development of experimental composites by reducing curing time. When the two concentrations of DPIHFP were compared, no statistically significant difference in shear bond strength was found for all light-activation times. In this study, increased molar concentration of iodonium salt did not increase the curing reactivity of the experimental composite. These results agree with those of a previous study where lower concentrations of iodonium salt had minor influence on the polymerization rate (15).

The second hypothesis was rejected, since significant differences were observed between shear bond strength for storage time at $24 \mathrm{~h}$ in relation to $10 \mathrm{~min}$ for all groups (bonding material or light-activation time). This result is in agreement with other studies, where the shear bond strength increased after $24 \mathrm{~h}$ in relation to $10 \mathrm{~min}(9,17,18)$. According to Leung et al. (23), post-polymerization of the composite, mainly in the first $24 \mathrm{~h}$, may be responsible for increase in SBS. For other authors $(24,25)$, any alteration in conversion in the latter curing stages may increase polymer crosslinking and improve polymer properties.

When light-activation times were compared, the SBS of the groups light-activated for 20 and $40 \mathrm{~s}$ at $10 \mathrm{~min}$ was significantly higher than for $8 \mathrm{~s}$ of the control group. No statistically significant differences were found among the light-activation times for the other groups tested at $10 \mathrm{~min}$ or groups tested at $24 \mathrm{~h}$. Therefore, the third hypothesis was partly accepted. According to Rueggeberg (5), polymerization of resin materials is dependent on the radiant exposure, which is the product of irradiance and exposure time. In this study, approximately $6.4,16$ and 32 $\mathrm{J} / \mathrm{cm}^{2}$ energy doses were used for specimens light-activated for 8,20 and $40 \mathrm{~s}$. These differences in energy doses may

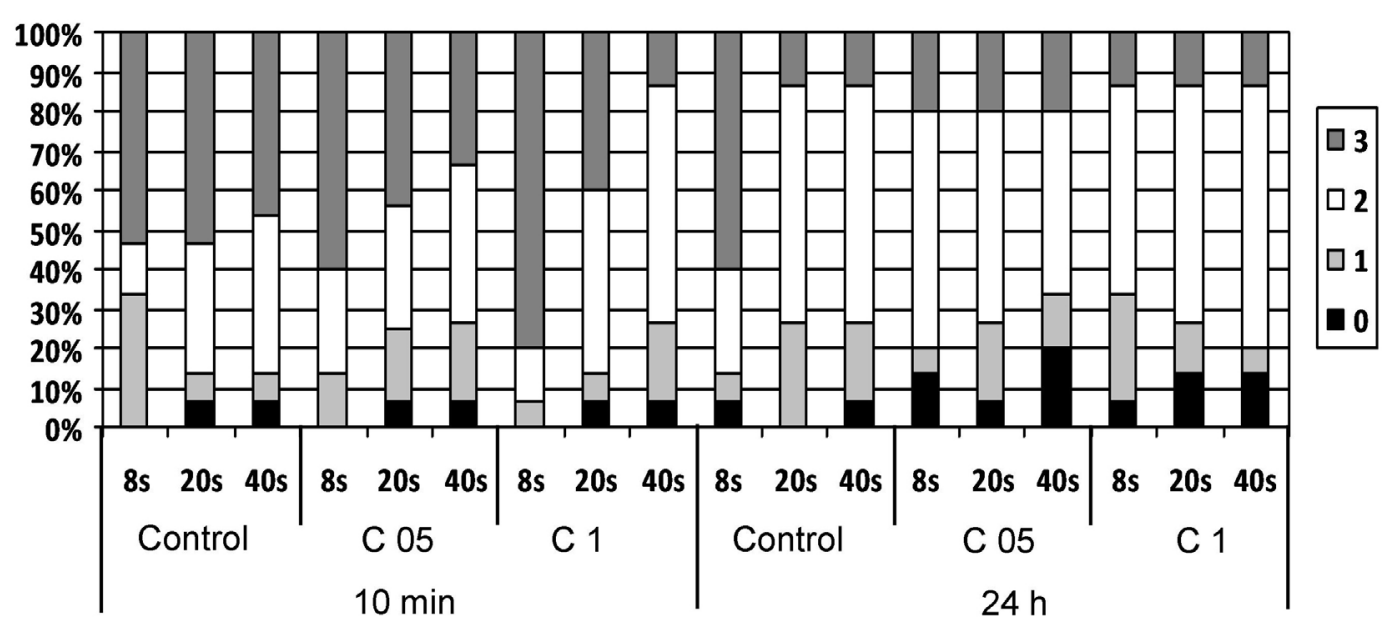

Figure 1. Frequency distributions (\%) of the Adhesive Remnant Index (ARI) scores for all groups. Score 0 indicates that no bonding resin remained on the tooth; Score 1 indicates that less than half of the bonding resin remained on the tooth; Score 2 indicates that more than half of the bonding resin remained on the tooth; and Score 3 indicates that all bonding resin remained on the tooth, along with a clear impression of the bracket mesh. 
explain the difference among the light-activation times for the control group at 10 min storage time.

The results of ARI scores indicated that the majority of debonding failures left all bonding resin on the tooth, along with a clear impression of the bracket mesh (score 3 ) at 10 min storage time and prevalence of score 2, where more than half of the bonding resin remained on the tooth, at $24 \mathrm{~h}$ storage time. Similar results were found in a previous study using iodonium salt-modified agents (9). According to Costa et al. (9), failures of modified materials tended to include fracture of the bonding material, indicating a better mechanical interlocking of the experimental composite with the bracket mesh, probably by improvements in the polymerization due to the addition of iodonium salt. In conclusion, the present study demonstrated that the addition of iodonium salt in the experimental composites may increase the bond strength of brackets bonded to bovine enamel using reduced light exposure times.

\section{Resumo}

Estudo investigou o efeito da incorporação de um sal de iodônio em compósito experimental, na resistência de união de braquetes metálicos fixados em dentes bovinos. Duzentos e setenta dentes bovinos foram embutidos e divididos em 18 grupos ( $n=15)$, de acordo com o compósito experimental com sal de iodônio na concentração molar de 0 (controle), 0,5 e $1 \%$; tempo de fotoativação $(8,20$ e 40 s); e, tempo de armazenagem (10 min e $24 \mathrm{~h}$ ). Braquetes metálicos foram fixados na superfície do dente usando compósitos experimentais. A fotoativação foi efetuada com 0 L. aparelho XL 2500 por 8, 20 e $40 \mathrm{~s}$. As amostras foram armazenadas em água 政 $37^{\circ} \mathrm{C}$ por 10 min e $24 \mathrm{~h}$ e submetidos ao ensaio de resistência de união à velocidade de $0,5 \mathrm{~mm} / \mathrm{min}$. Os dados foram submetidos à Análise de variância de 3 fatores e ao teste de Tukey $(\alpha=0,05)$. 0 Índice de Remanescente do Adesivo (IRA) foi usado para classificar os modos de falhas. Os valores de resistência de união ao cisalhamento ( $\mathrm{MPa}$ ) no período de 10 min para os tempos de fotoativação de 8,20 e 40 s foram: $\mathrm{G} 1$ - 4,6; 6,9 e 7,$1 ; G 2-8,1 ; 9,2$ e 9,9; G3 - 9,1; 10,4 e 10,7; e no período de 24 h foram: $\mathrm{G} 1$ - 10,9; 11,1 e 11,7; G2 - 11,8; 12,7 e 14,2; G3 - 12,1; 14,4 e 15,8 . Houve predominância de escore 3 para os grupos armazenados por 10 min e escore 2 para os grupos armazenados por $24 \mathrm{~h}$. Em conclusão, a adição do sal de iondônio ( $\mathrm{C} 05$ e C1) em compósitos experimentais pode aumentar a resistência de união de braquetes ao esmalte bovino usando reduzidos tempos de fotoativação.

\section{Acknowledgements}

This study was supported by the Conselho Nacional de Desenvolvimento Científico e Tecnológico - CNPq (Grant \#303928/2009-3). The authors acknowledge Esstech Inc. for supplying the reagents used in this study.

\section{References}

1. Romano $F L$, Correr $A B$, Correr-Sobrinho $L$, Magnani $M B$, Ruellas $A C$. Clinical evaluation of the failure rates of metallic brackets. J Appl Oral Sci 2012;20:228-234.

2. Costa $A R$, Correr $A B$, Puppin-Rontani RM, Vedovello $S A$, Valdrighi HC, Correr-Sobrinho $L$, et al.. Effects of thermocycling and light source on the bond strength of metallic brackets to bovine teeth. Braz Dent J $2011 ; 22: 486-489$.

3. Correr $A B$, Costa $A R$, Lucato $A S$, Vedovello $S A$, Valdrighi HC, Vedovello Filho $M$, Correr-Sobrinho L. Effect of activation mode on shear bond strength of metallic brackets. Braz Dent J 2013;24:513-516.
4. Sfondrini MF, Cacciafesta V, Scribante A, Klersy C. Plasma arc versus halogen light curing of orthodontic brackets: a 12-month clinical study of bond failures. Am J Orthod Dentofacial Orthop 2004;125:342-347.

5. Staudt CB, Krejci I, Mavropoulos A. Bracket bond strength dependence on light power density. J Dent 2006;34:498-502.

6. Rueggeberg F. Contemporary issues in photocuring. Compend Contin Educ Dent Suppl. 1999;25:4-15.

7. Stansbury JW. Curing dental resins and composites by photopolymerization. J Esthetic Dent 2000;12:300-308.

8. Sfondrini MF, Cacciafesta V, Pistorio A, Sfondrini G. Effects of conventional and high-intensity light-curing on enamel shear bond strength of composite resin and resin-modified glass-ionomer. Am J Orthod Dentofacial Orthop 2001;119:30-35.

9. Costa AR, Vedovello-Filho M, Correr AB, Vedovello SAS, Puppin-Rontani RM, Ogliari FA, et al.. Bonding orthodontics brackets to enamel using experimental composites with an iodonium salt. Eur J Orthod 2014;36:297-302.

10. Oesterle U, Newman SM, Shellhart WC. Rapid curing of bonding composite with a xenon plasma arc light. Am J Orthod Dentofacial Orthop 2001;119:610-616.

11. Staudt CB, Mavropoulos A, Bouillaguet $S$, Kiliaridis $S$, Krejci I. Lightcuring time reduction with a new high-power halogen lamp. Am J Orthod Dentofacial Orthop 2005;128:749-754.

12. Gonçalves PR, Moraes RR, Costa AR, Correr AB, Nouer PR, Sinhoreti MA, et al.. Effect of etching time and light source on the bond strength of metallic brackets to ceramic. Braz Dent J 2011;22:245-248.

13. Talbot TQ, Blankenau RJ, Zobitz ME, Weaver AL, Lohse CM, Rebellato J. Effect of argon laser irradiation on shear bond strength of orthodontic brackets: an in vitro study. Am J Orthod Dentofacial Orthop 2000;118:274-279.

14. Klocke A, Korbmacher HM, Huck LG, Kahl-Nieke B. Plasma arc curing lights for orthodontic bonding. Am J Orthod Dentofacial Orthop 2002;122:643-648.

15. Ogliari FA, Ely C, Petzhold CL, Demarco FF, Piva E. Onium salt improves the polymerization kinetics in an experimental dental adhesive resin. J Dent 2007;35:583-587.

16. Odian G. Introduction. In: Principles of Polymerization, 4th Edition. John Wiley \& Sons, Inc.: Hoboken, USA; 2004.

17. Bishara SE, Von Wald L, Olsen ME, Laffoon JF. Effect of time on the shear bond strength of glass ionomer and composite orthodontic adhesives. Am J Orthod Dentofacial Orthop 1999;116:616-620.

18. Oliveira AS, Barwaldt CK, Bublitz LS, Moraes RR. Impact of bracket displacement or rotation during bonding and time of removal of excess adhesive on the bracket-enamel bond strength. J Orthod 2014;41:124127.

19. Gonçalves LS, Moraes RR, Ogliari FA, Boaro L, Braga RR, Consani S. Improved polymerization efficiency of methacrylate-based cements containing an iodonium salt. Dent Mater 2013;29:1251-1255.

20. Artun J, Bergland S. Clinical trials with crystal growth conditioning as an alternative to acid-etch enamel pretreatment. Am J Orthod 1984;85:333-340.

21. Kim D, Stansbury JW. Kinetic pathway investigations of three component photoinitiator systems for visible-light activated free radical polymerizations. J Polymer Science Part A: Polymer Chemistry 2009;47:887-898.

22. Padon KS, Scranton AB. A mechanistic investigation of a three component radical photoinitiator system comprising methylene blue, $\mathrm{N}$-methyldiethanolamine, and diphenyliodonium chloride. Journal of Polymer Science Part A: Polymer Chemistry 2000;38:2057-2066.

23. Leung $\mathrm{RL}$, Fan $\mathrm{PL}$, Johnston WM. Post-irradiation polymerization of visible light-activated composite resin. J Dent Res 1983;62:363-365.

24. Burtscher P. Stability of radicals in cured composite materials. Dent Mater 1993;9:218-221.

25. Mohamad D, Young RJ, Mann AB, Watts DC. Postpolymerization of dental resin composite evaluated with nanoindentation and microRaman spectroscopy. Arch Orofacial Scienc 2007;2:26-31.

Received February 28, 2014 Accepted June 3, 2014 